\title{
PARADIPLOMASI KOTA BUKITTINGGI DENGAN MALAYSIA DALAM MENINGKATKAN KUNJUNGAN WISATA
}

\author{
Rika Isnarti, \\ Universitas Andalas \\ Email: rikaisnarti@soc.unand.ac.id \\ Muhammad Fhadly \\ Universitas Andalas \\ Poppy Irawan \\ Universitas Andalas
}

\begin{abstract}
Abstrak
Penelitian ini bertujuan untuk menjelaskan paradiplomacy pemerintah Kota Bukittinggi dalam meningkatkan kunjungan wisatawan Malaysia. Wisatawan Malaysia adalah jumlah tertinggi dari mengunjungi pariwisata Bukittingi. Tingginya angka kunjungan ini bermanfaat untuk sektor ekonomi terutama usaha kecil dan menengah. Penelitian ini menggunakan dua jenis data, yaitu dokumentasi dan wawancara. Hasil penelitian menunjukkan bahwa paradiplomacy pemerintah Kota Bukittinggi dilakukan melalui pendekatan yang berfokus pada sektor pendidikan dan budaya. Secara lebih spefisik paradiplomacy kota Bukittinggi memberikan manfaat bagi Bukittinggi untuk memperluas pasar UMKM dan berdampak pada optimalisasi produksi bordir desainer. Namun, pemerintah perlu bertindak untuk menarik lebih banyak wisatawan untuk meningkatkan manfaat ekonomi.
\end{abstract}

Kata Kunci: Bukittingi, Malaysia, Paradiplomacy, Bordir Kerancang, Ekonomi

\begin{abstract}
This research aims to explain paradiplomacy of Bukittinggi's government to Malaysia in order to improve number of Malaysian tourism to Bukittingi and the impact of the paradiplomacy. Malaysian tourism is the highest number of tourism visting Bukitting. This situation benefits bukittingi especially in the economy sector that can empower small and medium entreprises. However, the government needs to do actions to attract more tourists to Bukittingi to enhavce economic benefit. In International Relations, Substate doing international affairs can be done through paradiplomacy. The type of this research is descriptive analysis using two types of data, namely documentation and interviews. The results of the research showed that the paradiplomacy of Bukittinggi to several regions in Malaysia is carried out through an approach that focuses on the education and culture sectors. Paradiplomacy activities between Bukittinggi and several regions in Malaysia provide benefits to Bukittinggi in order to expand the MSME market and have impact on optimizing the production of kerancang embroidery.
\end{abstract}

Keywords: Bukittinggi, Malaysia, Paradiplomacy, Bordirkerancang, economic

PENDAHULUAN

Kota Bukittinggi merupakan salah satu daerah di Indonesia yang berada di
Provinsi Sumatra Barat yang memiliki luas wilayah yang sangat kecil yakni $25,239 \mathrm{Km}^{2}$. Daerah ini menjadi salah satu daerah yang 
wajib mengembangkan UMKM daerahnya dikarenakan perekonomian Bukittinggi sangat bergantung pada UMKM. Kementrian Perindustrian Indonesia melalui KIID (Kompetensi Industri Inti Daerah) telah menetapkan bahwa UMKM unggulan Kota Bukittinggi adalah bordir kerancang khas Bukittinggi. Dalam melakukan pengembangan terhadap bordir kerancang, pemerintah Bukittinggi telah melakukan berbagai upaya seperti pelatihan-pelatihan, pembentukan Kelompok

Usaha Bersama(KUB), serta memberikan dukungan melalui pengadaan event dan mengirimkan desainer lokal ke peragaan busana ke luar kota. Upaya tersebut dilakukan oleh Kota Bukittinggi untuk meningkatkan kualitas dari produk unggulan daerahnya. Setelah melakukan upaya dalam peningkatan kualitas, Bukittinggi selanjutnya berupaya untuk memperluas pasar dari produk unggulan tersebut melalui penjalinan kedekatan dengan beberapa negara.

Salah satu negara yang paling banyak meminati produk brodir kerancang dar Bukittingi adalah Malaysia. Malaysia telah menjadi mitra sejak lama bagi Kota Bukittinggi. Beberapa daerah di Malaysia telah menjalin kerja sama dengan Kota Bukittinggi yaitu Seremban, Kuala Lumpur, Pahang, dan Terengganu. Kedekatan ini menjadikan Malaysia menjadi target potensial dalam promosi produk bordir kerancang.

Sejalan dengan hal ini, Malaysia juga merupakan negara dengan kunjungan wisatawan asing terbesar ke Bukittinggi setiap tahunnya. Malaysia juga menyukai produk bordir kerancang khas Bukittinggi yang terbukti dengan banyaknya wisatawan Malaysia yang datang berbelanja ke berbagai toko penjual bordir kerancang di Bukittinggi setiap minggunya.

Hal-hal tersebut menjadikan Bukittinggi harus berupaya untuk meningkatkan kedekatannya dengan Malaysia agar dapat meningkatkan angka kunjungan wisatawan dari Malaysia dan berbanding lurus dengan penjualan bordir kerancang Bukittinggi.

\section{METODOLOGI}

Tulisan inimenggunakan metode kualitatif dengan Teknik pengumpulan data study kepustakaan dan wawancara mendalam. Penelitian kualitatif berguna untuk menggali lebih dalam makna-makna yang terkandung dalam data yang dikumpulkan. Untuk study kepustakaan penulis mengumpulkan dokumen-dokumen perjanjian kerjasama antara pemerintah kota Bukittingi dan Malaysia serta laporan kegiatan maupun event-event yang pernah diselenggarakan oleh kedua belah pihak ini. Sedangkan untuk wawancara mendalam, penulis melakukan wawancara dengan 
sejumlah staff pemerintah Kota Bukittingi seperti staff pemerintah kota bagian kerjasama dan hubungan luar negeri, staff dekranasda kota bukittingi, kepala dinas pariwisata, pemuda dan olahraga, kepala UMKM dan lainnya.

Setelah melakukan pengumpulan data baik secara wawancara maupun study dokumen, penulis melakukan seleksi pada dokumen yang dianggap sesuai dengan topik penelitian dan kemudian memberikan makna pada data-data yang telah didapatkan. Hal ini juga disesuaikan dengan kerangka konsep paradiplomacy yang memiliki tujuh kerangka kerja.

\section{KERANGKA PEMIKIRAN}

\section{Paradiplomasi}

Aktivitas hubungan luar negeri pemerintah daerah diistilahkan dengan paradiplomasi. Istilah paradiplomasi pada awalnya diperkenalkan oleh Panayotis Soldatos dan selanjutnya sering digunakan oleh Ivo Duchacek. Paradiplomasi mengemukakan bahwa keterlibatan aktor subnasional secara internasional merupakan fenomena kompleks yang memiliki berbagai alasan dalam keterlibatannya dengan hubungan negara bangsa, yang mana bergantung pada isu dan situasi yang sedang dimainkan (Fritz Nganje, The Hague Journal of Diplomacy 9, no. 2 (2014): 11949).
Dalam kajian Hubungan Internasional, paradiplomasi merupakan kajian yang masih relative baru dan belum ada kerangka konseptual besar yang dapat digunakan untuk menganalisis aktivitas paradiplomasi Andre Lecours, International Negotiation 7, no. 1 (2002): 91-114).

Namun, Alex Sergunin dan Pertti Joenniemi di dalam tulisannya yang berjudul "Paradiplomacy as a Capacity Building Strategy The Case of Russia's Northwestern Subnational Actors" mengemukakan dua jenis metode baru dari paradiplomasi yaitu secara langsung(di mana daerah akan mengembangkan aktivitas paradiplomasinya sendiri) dan tidak langsung( di mana daerah akan mencoba untuk mempengaruhi kebijakan luar negeri federal). Di dalam penelitian ini, peneliti akan menggunakan metode secara langsung yang dipaparkan oleh Alex Sergunin dan Pertti Joenniemi dalam menganalisis aktivitas paradiplomasi Kota Bukittinggi dengan Malaysia. Metode langsung dari paradiplomasi terdiri atas tujuh indikator yaitu Alexander Sergunin and Pertti Joenniemi, 2018: 18-33):

\section{Membuat fondasi legal}

Taktik ini sangat penting untuk aktor subnasional yang masih lemah dan membutuhkan legitimasi. Aktor subnasional cenderung akan berusaha untuk membuat negara menciptakan dasar hukum yang memberikan wewenang kepada aktor 
subnasional untuk dapat melakukan hubungan internasional.

\section{Menggunakan treaty-making power}

Pada strategi ini, aktor subnasional cenderung menggunakan power yang dimilikinya untuk membuat treaties dengan negara lain atau aktor subnasional dari negara lain. Luas wilayah, sosioekonomi dan potensi budaya memiliki pengaruh yang signifikan terhadap intensitas dari pembuatan treaties oleh aktor subnasional. Di Russia, strategi pembuatan treaties telah menjadi instrument yang efektif untuk membangun kapasitas dan menegaskan prestise domestik dan internasional.

3. Membentuk kantor representatif di negara asing

Untuk memfasilitasi kerja sama dengan negara asing dan meningkatkan kedekatan antara mitra kerja sama, beberapa kawasan di Russia mengatur suatu misi perdagangan dan budaya keluar negeri. Kerugian dari strategi ini yaitu akan membutuhkan dana yang cukup besar untuk melaksanakannya. Sebagian besar negara di Russia cenderung bergantung pada kedutaan federal, konsulat, dan misi perdagangan untuk mengejar kebijakan luar negeri mereka.

4. Menarik invesmen asing dan mempromosikan proyek bersama

Di Russia, beberapa daerah telah berhasil dalam menciptakan kondisi yang baik untuk investasi asing seperti pajak yang rendah dan pejabat lokal yang antusias. Semakin "ramah invesmen" suatu daerah, maka akan semakin mudah daerah tersebut untuk menarik investasi asing yang berdampak pada peningkatan FDI di daerah tersebut.

\section{Membuat citra positif keluar negeri}

Untuk menarik investment asing, daerah di Russia melakukan pendekatan melalui kampanye hubungan masyarakat. Contohnya mereka melakukan pameran, mengadakan "cooperation days" atau festival dengan kota kembar, ikut serta dalam pertemuan internasional, dan menaruh iklan pada media dari mitranya. Pemimpin daerah dan kota melakukan perjalanan keluar negeri secara regular sebagai usaha untuk hubungan masyarakat. Beberapa daerah ada yang membuat website bilingual yang berorientasi untuk audiens asing. Tujuan utama dari kampanye tersebut adalah untuk mempromosikan citra dari aktor daerah sebagai platform yang kreatif dan inovatif, bukan sebagai area yang terpencil dan tertekan.

6. Bekerja sama dengan organisasi internasional

Untuk mendemonstrasikan keuntungan kompetitif dari marginalitas dan mengkonfirmasi status mereka sebagai aktor global, beberapa daerah di Russia mencoba 
untuk menjalin hubungan dengan organisasi internasional. Perlu diingat bahwa kerja sama dengan organisasi internasional merupakan hal penting bagi unit subnasional bukan hanya untuk mendapat dukungan lebih dari negara, namun juga untuk melibatkan diri dalam proses globalisasi dan regionalisasi.

\section{Meningkatkan Keterikatan}

Keterikatan merupakan hal yang penting dalam menjalin hubungan internasional oleh aktor subnasional. Strategi keterikatan sangat bergantung pada persamaan sejarah. Bentuk dari persamaan sejarah ini misalnya kesamaan kebangsaan, ras, bahasa, budaya, kedekatan wilayah, sama-sama wilayah jajahan dari penjajah yang sama maupun persamaan cerita masa lalu. Kota kembar telah menjadi bentuk dari kerja sama daerah paling sukses dan teori keterikatan terpakai pada kasus ini. Sebagai aspek dari regionalisasi, kota kembar menunjukkan bahwa batas nasional telah kehilangan kapasitasnya untuk memaksakan tatanan. Bahkan hal ini menjadikan marjinalitas yang merupakan suatu bentuk kerugian menjadi keuntungan kompetitif dan meningkatkan keterikatan. Di wilayah Eropa Utara, twinning menjadi satu metode yang digunakan oleh kota untuk menciptakan profil yang berbeda, terkenal, dan baik.

\section{PEMBAHASAN}

Berdasarkan upaya paradiplomasi yang dijabarkan oleh Alex Sergunin dan Pertti
Joenniemi, peneliti akan menjabarkan satu per satu mengenai bagaimana upaya paradiplomasi yang dilakukan oleh Kota Bukittinggi dengan beberapa daerah di Malaysia untuk meningkatkan kedekatannya dengan mitra kerja samanya.

\section{Membuat Fondasi Legal}

Pada dasarnya, fondasi legal dibutuhkan oleh pemerintah daerah untuk menjadi landasan utama hubungan internasional yang mereka lakukan dan sebagai legalitas dari kerja sama mereka. Biasanya bentuk dari fondasi legal ini terdiri dari aturan/hukum pemerintah pusat untuk memberikan wewenang pada pemerintah daerah untuk melakukan hubungan internasional serta MoU yang dibuat oleh pemerintah daerah dengan mitra kerja samanya.

Dalam bentuk aturan/hukum serta wewenang dari pemerintah pusat, Bukittinggi bersandar pada undang-undang Indonesia terkait aktivitas hubungan internasional oleh pemerintah daerah, diantaranya UU No. 37 Tahun 1999 pada pasal 1 ayat (1) yang berbunyi:

"Hubungan Luar Negeri adalah setiap kegiatan yang menyangkut aspek regional dan internasional yang dilakukan oleh Pemerintah di tingkat pusat dan daerah, atau lembagalembaganya, lembaga negara, badan usaha, organisasi politik, organisasi masyarakat, lembaga swadaya 
masyarakat, atau warga negara

Indonesia”.

Selanjutnya, melalui UU No.32 Tahun 2004 lebih memperjelas teknis dari hubungan internasional yang dilakukan oleh aktor subnasional yang ada di Indonesia yaitu setiap aktivitas hubungan internasional harus disetujui terlebih dahulu oleh DPR.

Selain itu, mengenai kegiatan dari aktivitas paradiplomasi pemerintah daerah juga diatur melalui Peraturan Menteri Luar Negeri Nomor 09/A/KP/XII/2006/01 yang meliputi; a. Bidang kerja sama ekonomi yang mencakup perdagangan, investasi, ketenagakerjaan, kelautan, perikanan, IPTEK, pertanian, kehutanan, pertambangan, kependudukan, pariwisata, lingkungan hidup, dan perhubungan; b. Bidang kerja sama sosial budaya, yakni pendidikan, kesehatan, kepemudaan, kewanitaan, olah raga dan kesenian, serta bidang kerja sama lainnya (Takdir Ali Mukti,2013).

Berdasarkan landasan-landasan legal tersebut, Bukittinggi memiliki wewenang yang cukup untuk menjalankan hubungan luar negeri dengan Malaysia. secara legal, Indonesia telah mengizinkan kerja sama yang dilakukan oleh Kota Bukittinggi dikarenakan kerja sama yang dilakukan oleh Kota Bukittinggi bergerak di sektor pendidikan, pariwisata, dan sosial budaya yang merupakan sektor yang diizinkan.

Selanjutnya, landasan legal Kota Bukittinggi untuk melakukan kerja sama dengan Malaysia yaitu melalui MoU yang telah disepakati antara Kota Bukittinggi dan Malaysia. Telah dijabarkan pada bab sebelumnya, MoU yang telah disepakati antara Kota Bukittinggi dengan Malaysia sangat banyak dan hal ini menjadi pijakan bagi Bukittinggi untuk menginisiasi kerja sama lainnya dan bagaimana Bukittinggi melakukan aktivitas terkait kerja sama dengan Malaysia.

\section{Menggunakan Treaty-making power}

Menurut definisi yang merujuk pada "Vienna Convention on the law of treaties" tahun 1969, treaty adalah sebuah perjanjian formal yang mengikat, kontrak, atau instrument tertulis antara dua atau lebih subjek hokum internasional. Secara umum, istilah treaty sendiri menggambarkan keberagaman dari instrument diantaranya konvensi, perjanjian, penyusunan, protokol, piagam, serta tindakan. Diantara instrument tersebut, banyak juga yang tidak bisa dikategorisasikan sebagai treaty. Kunci pembeda antara instrument yang merupakan treaty dan bukan treaty terletak pada sifatnya yang mengikat (Malcolm Shaw, 2018).

Di dalam jurnal "Paradiplomacy as a Capacity Building Strategy the Case of Russia's Northwestern Subnational Actors", 
Pertti Joenniemi dan Alex Sergunin menjelaskan bagaimana pentingnya menggunakan power yang dimiliki oleh pemerintah subnasional untuk membuat treaty dengan aktor subnasional ataupun pemerintah nasional negara lain. Bagi pemerintah subnasional, treaty berguna sebagai instrumen untuk menunjukkan kekuatan serta memperkuat posisi di dalam negara serta meningkatkan keterlibatan mereka dalam hubungan internasional. Biasanya, hal yang menjadi kekuatan bagi pemerintah subnasional dalam menarik negara lain untuk membuat treaty yaitu luas wilayah, potensi sosio ekonomi dan potensi budaya.

Dalam hubungan antara Bukittinggi dengan Malaysia, hal yang menjadi kekuatan utama adalah kualitas dan kapasitas dari sektor pendidikan Kota Bukittinggi. berdasarkan MoU yang telah disepakati didapatkan bahwa kerja sama paling banyak yang dilakukan antara Kota Bukittinggi dengan Malaysia adalah kerja sama di bidang pendidikan. Pada tahun 2014, Malaysia menyatakan keinginannya kepada Bukittinggi untuk meningkatkan kerja sama di bidang pendidikan yang sebelumnya terputus pada tahun 2010. Berdasarkan hal tersebut dapat dilihat bahwa Malaysia memandang sektor pendidikan Kota Bukittinggi sebagai suatu sektor yang menguntungkan bagi Malaysia untuk bekerja sama. Selanjutnya kekuatan utama dari daya tawar Kota Bukittinggi dalam membuat treaty adalah sektor kebudayaan yang juga terlihat dari banyaknya kerja sama yang diinisiasi Malaysia dengan Bukittinggi pada sektor ini. Selain itu, Bukittinggi juga selalu merespon secara positif dan menunjukkan keseriusannya dalam melakukan kerja sama dengan Malaysia yang terlihat dari setiap undangan untuk mengadakan kunjungan dari Malaysia untuk Bukittinggi, Bukittinggi selalu datang untuk memenuhi undangan tersebut. Biasanya juga pemerintah Bukittinggi juga selalu diwakilkan oleh pemimpin daerah serta beberapa kepala dinas terkait setiap adanya undangan dari Malaysia untuk menginisiasi kerja sama.

Selanjutnya yang menjadi kekuatan dalam pembuatan treaty bagi pemerintah Kota Bukittinggi yaitu wewenang yang telah diberikan Indonesia pada pemerintah daerah untuk melakukan aktivitas paradiplomasi. Berdasarkan yang telah dijelaskan sebelumnya, landasan legal merupakan hal yang penting dalam penginisiasian kerja sama pemerintah subnasional. Indonesia yang telah memberikan wewenang menyebabkan Bukittinggi menjadi lebih mudah dalam membuat treaty dengan Malaysia dan dasar hukum tersebut ikut memperkuat daya ikat treaty antara Bukittinggi dan Malaysia. 
Selain itu, pemberlakuan MEA juga menjadi salah satu kekuatan bagi Bukittinggi untuk menarik Malaysia dalam menginisiasi pembentukan treaty. Hal ini peneliti temukan melalui peningkatan penandatanganan $\mathrm{MoU}$ yang signifikan pada tahun 2015, di mana tahun ini bertepatan dengan pemberlakuan MEA. Pemberlakuan MEA bisa dikatakan sebagai pendorong kedua pihak untuk meningkatkan intensitas kerja sama. Hal ini diperkuat dengan pernyataan Kepala Dinas Pendidikan Kota Bukittinggi yang menjabat yakni Bpk. Melfi Abra. Beliau menyatakan bahwa:

“MEA telah menjadi link kerja sama antara Bukittinggi dengan negaranegara di ASEAN. Link tersebut tidak hanya dalam hal ekonomi dan perdagangan saja, tetapi link kerja sama dalam berbagai sektor termasuk pariwisata dan pendidikan." Melfi Abra, 2018)

Berdasarkan pernyataan beliau, dapat diindikasikan bahwa MEA menjadi salah satu hal yang melandasi peningkatan kerja sama antara Bukittinggi dengan negara yang ada di ASEAN, khususnya Malaysia. hal ini juga terlihat pada peningkatan yang signifikan dalam hal jumlah MoU pada tahun berikutnya, yakni tahun 2016. Dan jumlah wilayah yang bekerja sama dengan Bukittinggi pun tidak hanya terbatas wilayah Seremban yang notabene telah melakukan kerja sama sister city dengan Bukittinggi saja, namun juga wilayah lainnya seperti Terengganu dan Pahang.

\section{Membentuk kantor representatif di negara asing}

Kantor representatif di negara lain sangat penting dalam hal peningkatan kedekatan antara pemerintah subnasional dengan negara mitra serta untuk memfasilitasi kerja sama secara langsung dengan negara mitra. Dalam membentuk kantor representatif di negara lain, hal yang selalu menjadi kendala bagi aktor subnasional adalah masalah pendanaan karena untuk membentuk kantor representatif, biayanya tidaklah murah (Alexander Sergunin and Pertti Joenniemi, 2018). Berdasarkan yang dipaparkan oleh Alex Sergunin dan Pertti Joenniemi di dalam jurnalnya, di Russia sendiri, banyak pemerintah subnasional yang bergantung pada pemerintah federal, kedutaan, serta konsulatnya sebagai solusi dari permasalahan mengenai pembentukan kantor representatif di negara lain.

Sebagai wilayah dengan luas yang kecil dan anggaran yang tidak terlalu besar, sangat sulit bagi Kota Bukittinggi untuk membentuk kantor representatif khusus di Malaysia. Peneliti juga menemukan bahwa Bukittinggi juga tidak memiliki representasi di Malaysia. Namun, Bukittinggi menyiasasti taktik ini dengan menjalin hubungan yang dekat dengan Wakil Duta Besar Indonesia 
untuk Kuala Lumpur serta secara tidak langsung memanfaatkannya untuk mempromosikan kepentingan Bukittinggi di Malaysia.

Hal ini dapat dilihat dari pernyataan oleh Wakil Duta Besar Indonesia untuk Malaysia yakni Tri Gustono Supriyanto pada tanggal 08 Desember 2016. Beliau menyatakan bahwa:

"Pihak Kedubes RI di ibu negara Malaysia berjanji akan membantu dan memfasilitasi berbagai program yang telah disusun Pemko Bukittinggi, terutama mempromosikan berbagai produk unggulan daerah. Sebagai perwakilan Pemerintah RI di Malaysia, KBRI Kualalumpur akan selalu siap untuk mempromosikan potensi Bukittinggi, terutama sekali di lingkungan masyarakat negara tetangga serta warga negara lain yang ada di Malaysia. Pokoknya, Pemko Bukittinggi harus menjalin komunikasi yang intens dengan pihak KBRI, sehingga berbagai informasi dapat disharing secara baik nantinya. (Rahmat Illahi, 2018).

Hal ini merupakan respon positif dari permintaan Walikota Bukittinggi, Bpk. M. Ramlan Nurmatias pada Kedubes RI di Malaysia pada jamuan makan malam yang diadakan pada 05 Desember 2016 di Objek Wisata Benteng Ford De Kock. Jamuan ini dijadikan sebagai media bagi Bukittinggi untuk menjalin kedekatan dengan Kedubes
RI di Malaysia. Pada jamuan tersebut, beliau mempromosikan kepentingan dari Bukittinggi melalui pemaparan mengenai potensi yang dimiliki oleh Kota Bukittinggi kepada Kedubes RI untuk Malaysia dan meminta agar beliau mau mempromosikan Kota Bukittinggi di Malaysia.

Pada tanggal 06 Desember 2016, pertemuan dalam rangka silaturrahmi telah diadakan yang dipimpin langsung oleh Wakil Duta Besar Tri Gustono Supriyanto dan didampingi Atase Bidang Ketenaga Kerjaan Mustafa Kamal, Atase Bidang Pendidikan Prof. DR. Ari Purbayanto, Atase Bidang Perdagangan Fajarini Punto Dewi serta Kepala Sekolah Indonesia di Malaysia Agustinus Suharjo. Pihak KBRI juga mengikutkan dua orang anggota Dewan Perniagaan Melayu Malaysia (DPMM) Kualalumpur masing-masing Dato Abdul Manaf Hanafi dan Nizam(Rahmat Illahi, 2018). Pertemuan ini juga dihadiri kepala SKPD, kepala sekolah dan pelaku usaha kepariwisataan, seperti PHRI dan Asita.

Di dalam pertemuan ini, Wakil Walikota Bukittinggi, Bpk. Irwandi menyampaikan secara detail kepentingan dari kota Bukittinggi untuk didapatkan melalui kerja sama dengan Malaysia pada empat sektor unggulan yaitu pariwisata, perdagangan, pendidikan, dan kesehatan. Pemerintah Kota Bukittinggi meminta KBRI Malaysia untuk membantu Bukittinggi dalam 
promosi sektor tersebut di Malaysia. Salah satu permintaan Walikota Bukittinggi kepada KBRI Malaysia yaitu di bidang UMKM dimana walikota berharap KBRI dapat menyediakan ruang khusus untuk promosi produk khas Bukittinggi, sehingga dapat dikenal masyarakat di Negara Malaysia, terutama usaha bordir, sulaman dan kerajinan lainnya. Pemko Bukittinggi nantinya juga akan menempatkan seorang pegawai khusus pada tempat promosi tersebut. KBRI Malaysia juga sangat diharapkan untuk memuluskan peluang pemasaran produk bordir kerancang sekaligus menjadi. Selanjutnya, Atase Perdagangan dan Dewan Perniagaan Melalui Malaysia (DPMM) Kuala lumpur juga diharapkan untuk dapat menjembatani pengenalan dan penjajakan kemitraan antara UMKM dan para pengusaha dengan calon pengusaha serta pembeli di Malaysia. selanjutnya, Atase Bidang Pendidikan diharapkan perannya memfasilitasi kerja sama melalui kota kembar dan pertukaran pelajar yang telah dikembangkan selama ini (Rahmat Illahi, 2018).

\section{Menarik Investor Asing dan}

\section{Mempromosikan Proyek Bersama}

Dalam meningkatkan kapasitas yang dimilikinya, aktor subnasional perlu mencari taktik bagaimana cara menarik investor asing ke daerahnya. Pada dasarnya salah satu tujuan utama hubungan internasional bagi pemerintah subnasional adalah untuk menarik investor asing. Namun, dalam hubungan antara Kota Bukittinggi dengan Malaysia, belum ada proyek bersama yang telah dilakukan dalam rangka untuk menarik investor dari Malaysia. namun, pemerintah Bukittinggi telah melakukan serangkaian upaya untuk selanjutnya dapat menarik Malaysia untuk melakukan hal tersebut.

Salah satu upaya yang dilakukan oleh Kota Bukittinggi untuk menarik investor yaitu melalui perbaikan dalam hal pelayanan. Menurut Kepala Dinas Pendidikan Kota Bukittinggi, Melfi Abra, Bukittinggi telah memperbaiki sistem pelayanannya sehubungan dengan diberlakukannya MEA melalui peningkatan sistem pelayanan terpadu untuk memudahkan investasi, kemudahan perizinan barang dan jasa. Adanya kemudahan di bidang investasi akan mendorong peningkatan jumlah investasi yang masuk ke daerah, khususnya Kota Bukittinggi. Selain itu, kemudahan perizinan barang dan jasa menjadi keuntungan bagi pelaku UMKM untuk melakukan kegiatan ekspor maupun impor barang sehingga UMKM dapat terus berkembang mengikuti arus global (Melfi Abra,, 2018).

Selanjutnya, upaya yang dilakukan oleh pemerintah Kota Bukittinggi dalam menarik investor yaitu melalui pengembangan wisata MICE(Meeting, Incentive, Conference, dan Exhibition). 
Konsep wisata MICE diklaim menjanjikan kenaikan pendapatan daerah, meningkatkan citra Kota Bukittinggi sebagai kota yang aman, memacu investasi, dan membuka lapangan kerja (Elisa Karamoy, 2015). Hal ini sejalan dengan salah satu misi Kota Bukittinggi di dalam RPJMD Kota Bukittinggi tahun 2016-2021 tentang mewujudkan pariwisata yang berdaya saing. Dimana salah satu kebijakan strategis pemerintah yaitu mengembangkan dan memfasilitasi sarana dan prasarana untuk mendukung wisata berbasis MICE.

Upaya terakhir yang peneliti temukan yakni penyelenggaraan event Minangkabau Travel Mart. Event ini merupakan event tahunan yang diinisiasi sejak tahun 2014 dan dimulai dari pengumpulan para pelaku usaha pariwisata yang ada di Bukittinggi untuk sebagai ajang promosi bagi para pelaku usaha. Kemudian acara ini selalu berkembang dengan ikut mengundang pihak Malaysia baik pemerintah, maupun pelaku usaha serta calon investor (Melfi Abra,2018). Pada tahun 2017, Minangkabau Travel Mart telah diikuti oleh 1200 pelaku pariwisata dari Malaysia, Indonesia, Brunei dan Singapura. Menurut Bapak Erwin Umar, Kepala Dinas Pariwisata Kota Bukittinggi, pendapatan Kota Bukittingi dari kunjungan pariwisata naik 102\% dari tahun 2016 hingga tahun 2017.

\section{Membuat citra positif keluar negeri}

Untuk mempererat hubungan dengan negara mitra, membangun citra yang baik merupakan salah satu strategi yang penting bagi pemerintah subnasional. Dalam membangun citra ini bisa melalui berbagai cara seperti melakukan kunjungan secara rutin, kampanye, dan membuat event dengan mitra kerja sama. Citra yang dibangun tidak hanya berguna bagi pemerintah di kedua negara, tapi juga sangat efektif untuk meningkatkan kepercayaan warga di kedua wilayah yang bekerja sama dan untuk menjamin kerja sama akan selalu berkelanjutan.

Saat ini, citra Bukittinggi di Malaysia sudah bisa dikatakan sangat baik. Hal ini dijelaskan oleh Bpk. Melfi Abra, Kepala Dinas Pariwisata Kota Bukittinggi tahun 2014-2016, dimana beliau mengatakan bahwa Citra bukittinggi di Malaysia sangat baik yang terbukti dengan wisatawan dari Malaysia yang banyak datang mengunjungi Bukittinggi. Bagi para wisatawan mancanegara, khususnya dari Malaysia, harga-harga barang dan makanan Bukittinggi juga terkenal terjangkau. Selain itu, biaya akomodasi dan transportasi juga cukup terjangkau bagi para wisatawan. Citra yang baik ini juga dilatar belakangi oleh adanya rasa kesamaan budaya antara orang Malaysia dan Bukittinggi. Para wisatawan dari Malaysia yang datang biasanya sudah cukup familiar dengan budaya Minangkabau. Hal 
ini tentunya tidak terlepas dari istilah "saudara serumpun" yang menjadikan orang Melayu dan Minangkabau memiliki kesamaan aspek-aspek budaya.

Meskipun demikian, pemerintah Kota Bukittinggi selalu berusaha untuk menjaga agar citra Bukittinggi tetap baik di Malaysia. Beberapa upaya yang telah dilakukan pemerintah Bukittinggi yaitu melalui kunjungan rutin setiap tahunnya saat mengantarkan para siswa dan guru pertukaran pelajar. Melalui kunjungan rutin ini, pemerintah Bukittinggi berupaya untuk mempromosikan Kota Bukittinggi terkhusus pada sektor pariwisata. Selain itu, para siswa yang dikirim dalam program pertukaran pelajarpun dibekali pengetahuan mengenai pariwisata Bukittinggi dan diberikan pamflet, kalender, serta CD pariwisata Bukittinggi agar mereka juga dapat mempromosikan Bukittinggi saat melakukan program pertukaran pelajar di Malaysia (Melfi Abra,, 2018).

Selain itu, setiap pihak Malaysia mengadakan acara, Pemko Bukittinggi selalu diundang dan diberikan kesempatan untuk menunjukkan kesenian khas daerah dan promosi budaya lainnya. Salah satu acara tersebut yaitu Festival Serempak Melayu dan Gendang Melayu. Event-event ini biasanya diselenggarakan setiap tahun dengan menampilkan kekhasan budaya daerah sekaligus dijadikan ajang untuk promosi pariwisata. Selain itu, saat diadakan seminar pun juga saling mengundang seperti pada seminar "Dunia Melayu Dunia Islam” yang diadakan oleh Malaysia mengundang pemerintah Bukittinggi untuk hadir.

Bentuk pencitraan lainnya yang dilakukan oleh pemerintah Kota Bukittinggi yaitu melalui media social. Media ini dimanfaatkan oleh pemerintah untuk promosi pariwisata Bukittinggi serta perbaikan citra Bukittinggi itu sendiri. Media social yang saat ini digunakan untuk promosi wisata adalah Twitter dan Instagram dengan username@bukittinggiku, serta Youtube dengan channel bernama Bukittinggi TV. Salah satu bentuk nyata aksi promosi yang dilakukan oleh pemko yaitu saat nasi kapau dituding memasang harga tinggi untuk para wisatawan. Melalui kampanye media sosial ini, pemerintah mencoba untuk menyosialisasikan bahwa hal tersebut tidak benar. Sosialisasi ini dilakukan melalui vlog dan kampanye media sosial lainnya sehingga dapat memperbaiki citra nasi kapau yang telah buruk di mata para wisatawan.

\section{Bekerja sama dengan organisasi internasional}

Biasanya upaya ini dilakukan oleh pemerintah subnasional untuk mengkonfirmasi statusnya sebagai aktor global. Pada dasarnya, kerja sama dengan organisasi internasional merupakan hal penting bagi unit subnasional bukan hanya 
untuk mendapat dukungan lebih dari negara, namun juga untuk melibatkan diri dalam proses globalisasi dan regionalisasi.

Meskipun taktik ini sangat penting bagi pemerintah subnasional, namun peneliti menemukan bahwa Bukittinggi belum memiliki kerja sama dengan organisasi internasional. Bentuk kerja sama yang dilakukan Bukittinggi masih terbatas pada kerja sama dengan negara. Di sini peneliti melihat bahwa kerja sama dengan organisasi internasional belum menjadi hal yang utama bagi Kota Bukittinggi dikarenakan status Bukittinggi sebagai aktor global sebenarnya sudah dilegitimasi oleh Indonesia. Berbeda dengan yang dipaparkan oleh Alex Sergunin dan Pertti Joenniemi di dalam jurnalnya dimana pada saat itu pemerintah subnasional Russia sangat kekurangan dalam hal legitimasi dari negara sehingga butuh pengakuan akan status aktor mereka dan kerja sama dengan organisasi internasional menjadi salah satu cara untuk memperkuat status tersebut.

\section{Meningkatkan Keterikatan}

Keterikatan merupakan hal yang penting dalam menjalin hubungan internasional bagi aktor subnasional. Strategi ini sangat bergantung pada persamaan sejarah antara kedua pihak yang bekerja sama. Bentuk dari persamaan sejarah ini misalnya kesamaan kebangsaan, ras, bahasa, budaya, kedekatan wilayah, sama-sama wilayah jajahan dari penjajah yang sama maupun persamaan cerita pada masa lalu.

Untuk meningkatkan keterikatan dengan mitra kerja sama, pembentukan kota kembar telah menjadi salah satu cara yang paling ampuh bagi pemerintah subnasional. Di Eropa sendiri, pembentukan kota kembar telah menjadi metode untuk meningkatkan keterikatan antara pemerintah subnasional yang bekerja sama. Bagi Bukittinggi, pembentukan kota kembar dengan Seremban sejak tahun 1986 telah menjadi titik awal hubungan diplomatis antara Bukittinggi dengan Malaysia.

Seperti yang telah peneliti jelaskan pada bab sebelumnya, bentuk kerja sama kota kembar antara Bukittinggi dan Seremban menekankan pada lima focus utama yakni; 1. Peningkatan apresiasi/pertukaran kesenian dan kebudayaan, 2. Peningkatan kepariwisataan, 3. Pertukaran pengalaman di bidang kerajinan/industri rumah tangga, 4. Pertukaran pengalaman di bidang administrasi, pemerintahan dan pembangunan, 5. Pembinaan generasi muda dan olah raga (http://www.bukittinggikota.go.id/info/pern yataan-bersama).

Melalui pertukaran-pertukaran tersebut, secara tidak langsung keterikatan antara kedua belah pihak menjadi semakin terjalin. Pada dasarnya, Bukittinggi juga memang sudah memiliki banyak persamaan 
dengan Seremban baik dalam hal sejarah, kebudayaan, maupun bahasa dimana penduduk di Seremban mayoritas adalah masyarakat Minangkabau dan banyak penduduk yang mampu berbahasa Minang. Selain itu, berdasarkan Tambo di Minangkabau, kedua wilayah ini memang berasal dari rumpun yang sama (Pemerintah Bukittinggi, 2018). Persamaan ini menjadi landasan bagi Bukittinggi untuk membentuk kerja sama kota kembar dengan Seremban.

Dalam meningkatkan keterikatan ini, pendekatan budaya dilakukan oleh pemerintah Kota Bukittinggi. berdasarkan wawancara dengan kepala Dinas Pendidikan Kota Bukittinggi, Bpk Melfi Abra, didapatkan bahwa upaya untuk meningkatkan keterikatan ini dilakukan melalui event-event kebudayaan yang diadakan di Bukittinggi akan selalu mengundang Malaysia untuk terlibat seperti festival silek internasional yang diadakan di Bukittinggi selalu mengundang Malaysia sebagai peserta maupun pada acara seremonialnya. Selain itu, seluruh MoU di bidang pendidikan yang telah disepakati oleh Bukittinggi dengan beberapa wilayah di Malaysia selalu melibatkan kerja sama dalam bidang pertukaran budaya antara kedua belah pihak. Dan sejak tahun 2015, jumlah MoU yang disepakati meningkat secara signifikan dan pada setiap MoU menyepakati pertukaran budaya di dalamnya. Peneliti memandang hal ini sebagai salah satu upaya yang dilakukan oleh pemerintah Kota Bukittinggi dalam taktik meningkatkan keterikatan.

\section{Kesimpulan}

Untuk meningkatkan angka kunjungan wisatawan dari Malaysia, Bukittingi telah melakukan berbagai upaya promosi dan meningkatkan kedekatan hubungan dengan Malaysia.

Dalam rangka melakukan paradiplomacy kota bukitiingi ke Malaysia, terdapat lima strategi uatam yang dilakukan oleh pemerintah Kota Bukittingi yang berhasil meningkatkan jumlah kunjungan wisatawan asing dari Malaysi ke Bukitting.

Strategi yang belum dilakukan oleh Bukittingi yaitu menarik investor dari Malysia melalui proyek Bersama. Peneliti meihat hal ini disebabkan oleh masih belum adanya urgensi dari Kota Bukittingi untuk menginisiasi proyek Bersama dengan Malaysia dikarenakan dengan luas wilayah yang kecil. Selain itu sebagian besar kerjasama yang dilakukan oleh pemerintah Kota bukittingi dengan Malaysia juga berada pada sector budaya dan Pendidikan.

Secara umum, tujuan pemerintah kota Bukittingi melakukan paradiplomasi terutama ke Malaysia adalah untuk mengembangkan potensi dari daerahnya, bukan untuk menampkkan kehadiran dalam 


\section{Daftar Referensi}

Ali Mukti, Takdir. Paradiplomacy Kerja sama Luar Negeri oleh Pemda di Indonesia, The Phinisi Press Yogyakarta (2013), hal 80.

Ang, Alvin. "AEC 2015 : Challenges And Opportunities For Local Governments In ASEAN", CPG Online Magazine, 2016, accessed March 13, 2018, http://www.cpg-

online.de/2016/05/01/aec-2015-

challenges-and-opportunities-

for-local-governments-in-asean/.

Association of Southeast Asian

Nation, "ASEAN Economic Community - ASEAN | One

Vision One Identity One Community", ASEAN | One Vision One Identity One Community, last modified 2018, accessed March 12, 2018, http://asean.org/aseaneconomic-community/.

Bukittinggi, Pemerintah.

"Minangkabau - Negeri

Sembilan".

Bukittinggikota.Go.Id. Accessed

September

8, 2018. http://www.bukittinggikota.go.id /info/minangkabau-negerisembilan.

Bukittinggi, Pemerintah. "Pernyataan Bersama".

Bukittinggikota.Go.Id. Accessed August $\quad 18, \quad 2018$. http://www.bukittinggikota.go.id /info/pernyataan-bersama.

Haluan, Editorial. "Sulaman Dan Bordiran Bukittinggi Bikin Pengunjung IFW 2017 Terkagum-Kagum". Harian Haluan. Last modified 2017. Accessed October 4, 2018. https://www.harianhaluan.com/n ews/detail/63713/sulaman-danbordiran-bukittinggi-bikinpengunjung-ifw-2017terkagumkagum.

Illahi, Rahmat. "Silahturahmi Dengan KBRI Kualalumpur, Pemko Harapkan Fasilitasi Promosi Unggulan Bukittinggi

Minangkabaunews".

Minangkabaunews.Com. Last modified 2016. Accessed September 5, 2018. https://minangkabaunews.com/a 
rtikel-10934-silahturahmi-

dengan-kbri-kualalumpur-

pemko-harapkan-fasilitasi-

promosi-unggulan-

bukittinggi.html.

Karamoy, Elisa. "8 Keuntungan

Berinvestasi Properti Di Kota

Bukittinggi | Urbankompas".

Urbankompas. Last modified

2015. Accessed September 6, 2018.

http://www.urbankompas.com/8

-keuntungan-berinvestasi-

properti-di-kota-bukittinggi-2/.

Lecours, Andre. "Paradiplomacy:

Reflections On The Foreign

Policy And International

Relations Of Regions".

International Negotiation 7, no.

1 (2002): 91-114.

Nganje, Fritz. "The Developmental Paradiplomacy of South African

Provinces: Context, Scope and the Challenge of Coordination." The Hague Journal of Diplomacy 9, no. 2 (2014).

Sergunin, Alex, and Pertti Joenniemi.

Paradiplomacy As A Sustainable

Development Strategy: The

Case Of Russia'S Arctic

Subnational Actors. Ebook,
2014. Accessed March 15, 2018.

http://src-

h.slav.hokudai.ac.jp/publictn/eur

asia_border_review/ebr_v5n2/E

BR_v5n2_01.pdf.

Shaw, Malcolm. "Treaty Tnternational Relation". $\quad$ Encyclopedia Britannica. Last modified 2016. Accessed August 19, 2018. https://www.britannica.com/topi c/treaty.

Wuri. "Pesta Bordir Dan Kerancang Di Bukittinggi Fashion Look 2017 | Trend Khasanah". Trendkhasanah.Com. Last modified 2017. Accessed October $\quad 4, \quad 2018$. http://trendkhasanah.com/pestabordir-dan-kerancang-dibukittinggi-fashion-look-2017/ 